\title{
Improving Public Health and Environmental Protection Resulting from Superfund Site Investigation/Remediation ${ }^{1}$
}

\author{
G. Fred Lee, PhD, PE, DEE and Anne Jones-Lee, PhD \\ G. Fred Lee \& Associates \\ 27298 East El Macero Drive, El Macero, California 95618 \\ Tel: 530-753-9630 - Fax: 530-753-9956 - Email: gfredlee@aol.com \\ www.gfredlee.com
}

December, 2003

The authors have been involved in review of a number of Superfund sites, with respect to the adequacy of investigation and remediation relative to providing a high degree of public health and environmental protection for as long as the wastes and other hazardous chemicals present at the site are a threat. We have found that Superfund/hazardous chemical site investigations do not necessarily obtain the technical information needed to adequately assess the hazards to public health and the environment. Further, there is pressure on the US EPA and state regulatory agencies to relax Superfund site investigation and remediation requirements, especially as they relate to redevelopment of brownfield sites. However, Lee and Jones (1991a,b), Lee and Jones-Lee (1994, 1997, 1998, 1999, 2000a) and Lee (1997) have discussed problems with approaches that are being used in Superfund and hazardous chemical site remediation and brownfield redevelopment of hazardous chemical sites.

Some of these problems arise from the fact that there are a number of hazardous chemical site remediation issues that are not now being adequately addressed in conventional US EPA and state regulatory agency Superfund and hazardous chemical site investigation/remediation guidance and implementation. GAO (1994) reported on inconsistencies in the approach used at different Superfund sites in following the US EPA guidance. The authors have found that this is still occurring today, where two different National Priority List (NPL) Superfund sites, both administered through the US EPA Region 9, are following significantly different approaches with respect to investigating the translocation of hazardous chemicals from the soils to the surface through terrestrial vegetation. At one site, translocation is being explored as a means of site remediation. At another, it is being largely ignored, even though, as discussed below, there is evidence of translocation of hazardous chemicals at the site. The US EPA

\footnotetext{
${ }^{1}$ Presented in part at US EPA National TAG Conference, Nashville, TN, September 1516, 2000, and the US EPA National TAG Conference, Albuquerque, NM, February 28-March 1, 2003. Lee and Jones-Lee (2000).
} 
(1988a) Superfund site investigation guidance needs to be brought up to date and expanded to more adequately address many of the issues discussed herein.

The situation with respect to relying on regulatory agencies to conduct the comprehensive studies needed at Superfund/hazardous chemical sites is mixed, with respect to the detail that agencies and their staff will follow. Often, regulatory agencies find themselves in the position of having more work/responsibility than they can carry out with the resources available. This tends to lead to a situation where some regulatory agencies and their staff do not look for additional work/problems. Often, they will interpret the regulatory requirements in such a way as to do the minimum necessary to just fulfill their interpretation of the requirements. Examples of this situation are discussed in this paper.

This paper is based primarily on the experience that the authors have gained through serving as the US EPA supported Technical Assistance Grant (TAG) advisors to the public (Davis South Campus Superfund Oversight Committee) at the University of California, Davis (UCD), Department of Energy (DOE) Laboratory for Energy-Related Health Research (LEHR) national Superfund site. This site contains a mixture of radioactive and hazardous chemicals, as well as other solid wastes arising from the University of California, Davis, education and research operations. The LEHR site began operating at its present location in 1958. Research at LEHR through the mid-1980s focused on the health effects from chronic exposure to radionuclides, primarily radium-226 (Ra-226) and strontium-90 (Sr-90).

The radioactive wastes at this site arose primarily from Atomic Energy Commission sponsored research, involving feeding low-level strontium-90 and radium-226 to dogs (beagles). Some of the wastes from these operations were disposed of in shallow pits dug around the periphery of the dog pens. This approach was followed even though the University of California, Berkeley, faculty had determined in the 1950s that waste disposal in the Central Valley of California by land burial would lead to groundwater pollution. This situation was sufficiently well known by the late 1950s so that the American Society of Civil Engineers (ASCE, 1959) developed a landfilling manual that specifically discussed this type of problem.

These radioactive wastes include scintillation vials containing carbon-14 and tritium. Also, it appears that appreciable amounts of tritiated compounds were disposed of in one or more disposal pits, so that they have contaminated the groundwaters underlying the site with sufficient tritium to require remediation. 
The wastes from the animal hospitals/laboratories where the dogs were maintained after receiving the radioactivity were treated to some degree in Imhoff tanks, and the waste effluent from these tanks was disposed of by percolation in dry wells constructed at the site.

Also at this site were buried campus wastes from both residential as well as laboratory facilities. UCD constructed three campus landfills at this site. It also utilized a number of disposal pits. These landfills/pits received radioactive and hazardous chemicals, as well as a variety of so-called non-hazardous waste. One of the major pollutants at the LEHR site arose from UCD dumping waste chloroform into a pit located in one of the landfills. This waste chloroform has generated a plume of chloroform that extends offsite between half a mile to a mile from the point of disposal in one of the important aquifers underlying the site. This aquifer is used for both domestic and agricultural water supplies. A second deeper aquifer was also contaminated by chloroform, apparently, primarily through inter-aquifer transport in wells that penetrate both aquifers.

In addition to the radioactive and other wastes mentioned above, the LEHR site also contains chlorinated hydrocarbon pesticides, such as chlordane, which were used to control fleas on the dogs. Some of the soils at the LEHR site are highly contaminated by chlordane, through its handling and use.

Past and current UCD administrations have attempted to manage the campus liquid and solid wastes through the university's landfill and wastewater treatment plant facilities, rather than using public facilities. The approach used by the university administration was to attempt to dispose of the campus wastes at the least possible cost, largely ignoring the potential problems of burying wastes in shallow pits, with respect to future groundwater pollution. This approach, while saving the university administration a small amount of funds at the time of disposal, is now costing the US/California public many tens of millions of dollars in site cleanup/remediation. Unfortunately, this approach is still being used today by the current university administration in managing campus solid wastes.

The contamination of soils and groundwaters at the site was discovered and documented in the mid-1980s, and the site was put on the NPL list in 1994. In 1995 the Davis South Campus Superfund Oversight Committee (DSCSOC) was organized, with Ms. Julie Roth as its Executive Director. Drs. G. Fred Lee and Anne Jones-Lee were appointed as TAG advisors to the DSCSOC in 1995. They have been active participants in site investigation and remediation since that time. 
While the focus of this paper is on the LEHR site, the issues discussed have far wider implications for evaluating the adequacy of Superfund site/hazardous chemical site investigation and remediation. It is the authors' experience that problems of the type encountered at LEHR occur in both the federal and state Superfund programs. Throughout this paper, when the term "hazardous chemical site" is used, this terminology is designed to address both national and state Superfund sites, as well as other areas where there are hazardous or deleterious chemicals that can be adverse to public health and/or the environment.

\section{Regulatory Overview}

The regulation of the LEHR Superfund site investigation and remediation is being conducted under the supervision of the US EPA Region 9 and several state of California agencies including the California Department of Toxic Substances Control, the California Department of Health Services and the Central Valley Regional Water Quality Control Board. The US EPA Region 9 and the California Department of Toxic Substances Control are responsible for the overall Superfund site investigation/remediation. The Department of Health Services is responsible for overseeing the radiological site investigation/remediation. The Central Valley Regional Water Quality Control Board is primarily responsible for groundwater quality investigation/remediation.

The investigation of the site has been jointly conducted by the Department of Energy through its contractors and the University of California, Davis, through its contractors. At about monthly intervals, the remediation program managers (RPMs) hold a meeting to discuss the results of the previous month's activities and the plans for the next month. DSCSOC representatives and their TAG advisor participate in these meetings.

\section{Public Participation in Site Investigation/Remediation}

At the US EPA National TAG meeting in held in Albuquerque, NM, in late February 2003, a number of TAG groups indicated that they had experienced opposition to a TAG group representative(s) participating in RPM meetings. DSCSOC also experienced this problem at the LEHR site where the University of California, Davis, apposed DSCSOC participation in these meetings. With support of the US EPA and the other site RPMs, DSCSOC has been included in the RPM meetings. Since, ultimately, the public should support the Records of Decision for site remediation, it is far better to have the TAG group (or its equivalent, for non-TAG sites) representatives be active participants in the site 
investigation and planning of implementation as well as post-ROD monitoring and maintenance, including the five-year reviews of the site.

\section{Inadequate Definition of Constituents of Concern}

One of the most common significant problems with Superfund/hazardous chemical site investigation/remediation is that regulatory agencies at both the federal and state levels allow a very narrow definition of constituents of concern (COCs) compared to the potential arena of hazardous or otherwise deleterious chemical constituents that could be present at the site. At sites like the LEHR site, where there is a wide variety of campus laboratory wastes that have been deposited at the site over a many-year period, there can readily be a substantial number of hazardous chemicals that are not on the "Priority Pollutant" list, as well as those that are analyzed by conventional GC/MS procedures. There are about 85,000 chemicals in commerce today. A thousand new chemicals are added each year. Typical waste investigations show that only a very small part of the total organic carbon present in wastes and groundwaters is identified. Typical Superfund site investigations focus on a few hundred potentially hazardous chemicals (primarily the Priority Pollutants) and largely ignore the many thousands of chemicals that could be present at the site that could be adverse to public health and the environment.

The Priority Pollutant list was developed without adequate professional and public review. It focuses largely on rodent carcinogens (chlorinated chemicals). The use of this list by regulatory agencies is contrary to providing public health and environmental protection, since it leads to a complacency on the part of the regulatory agencies in assuming that, if the Priority Pollutants are not found in examining the site, then the site must not contain any of the many tens of thousands of chemicals that could exist at the site.

Also, the approach that is used is to focus on chemical concentrations of a few chemicals, failing to incorporate chemical impact assessment. There are a variety of biological assessment techniques for potential carcinogens, teratogens and mutagens that have not been incorporated into Superfund site investigation/remediation. The US EPA held a conference devoted in part to "Biological Test Methods" (US EPA, 1988b; Friedman, 1990), which reviewed the various approaches that were available to evaluate the potential biological impacts of hazardous chemicals. Testing procedures such as the Ames test, impacts on DNA, etc., could and should be incorporated into site investigation and evaluation of the adequacy of remediation. 
Lee and Jones-Lee (1994) have discussed the significant under-regulation of Superfund site investigation/remediation arising out of following a narrow scope of defining constituents of concern. The chemical concentration approach typically used at Superfund sites can also lead to significant over-regulation by focusing on total concentrations of constituents, rather than toxic, available and mobile forms. Far greater use of biological evaluation techniques should be made in Superfund/hazardous chemical site investigation and evaluating the adequacy of remediation than is being done today.

Recently, perchlorate has received national attention as a newly discovered long-term highly hazardous chemical that is present in many surface and groundwaters associated with its use as a rocket fuel. Perchlorate is an inorganic chemical that moves rapidly through groundwater systems. While it has been characterized as a rocket fuel pollution problem, there are other sources. Perchlorate has been found to be hazardous to humans at low concentrations. An example of the failure to conduct a comprehensive investigation of a hazardous chemical site occurs at the Aerojet hazardous chemical site near Sacramento, CA. The Aerojet facility was a rocket testing facility that had polluted the groundwaters at the site and offsite with chlorinated solvents. The regulatory agencies for this site allowed Aerojet to pump the polluted groundwaters, strip the VOC and reinject the air-stripped groundwater into the aquifer. Subsequently it has been found that the VOC air-stripped, reinjected groundwater also contains perchlorate. Now Aerojet has to re-extract the groundwater to remove the perchlorate.

A similar situation to that at Aerojet is developing at the LEHR site, where UCD has been allowed to pump groundwater, air-strip chloroform, and reinject the polluted groundwater. The reinjected groundwater contains a number of known pollutants that will likely have to be removed by re-pumping to the surface and treatment. The groundwater should have been treated properly the first time it was extracted, using techniques - such as activated carbon beds and reverse osmosis - that are designed to remove a wide variety of known as well as unknown/uncharacterized pollutants.

At the LEHR site the RPMs thus far have allowed the principal responsible parties (PRPs) to only consider six chemicals as COCs (chloroform, chromium-VI, nitrate, total dissolved solids, tritium and carbon-14). DSCSOC has had concerns that the LEHR site PRPs (DOE and UCD) have failed thus far to discuss the potential for other hazardous or deleterious constituents to exist at the LEHR site in wastes, stormwater runoff and groundwaters, and to conduct the investigation/remediation in such a way as to assume that, at some time in the 
future, additional COCs will be found at the LEHR site. An example of this type of situation is the recent finding that perchlorate is a constituent in roadside safety flares.

Silva (2003) of the Santa Clara Valley Water District, has discussed the potential for highway safety flares to be a significant source of perchlorate $\left(\mathrm{ClO}_{4}^{-}\right)$ contamination to water, even when the flares are 100-percent burned. According to Silva,

"A single unburned 20-minute flare can potentially contaminate up to 2.2 acre-feet [726,000 gallons] of drinking water to just above the California Department of Health Services' current Action Level of $4 \mu \mathrm{g} / \mathrm{L}$ [for perchlorate]."

Silva points out that, "More than 40 metric tons of flares were used/burned in 2002 alone in Santa Clara County." Silva also indicates that fully burned flares can leach up to almost 2,000 $\mu \mathrm{g}$ of perchlorate per flare. It should be noted that California's Office of Environmental Health Hazard Assessment (OEHHA) (DHS, 2003) is conducting an evaluation of the hazards of perchlorate in drinking water. The $4 \mu \mathrm{g} / \mathrm{L}$ current action level is based on the detection limit. It is possible that the OEHHA evaluation will result in a decrease in the action level for perchlorate in drinking water. An issue that needs to be considered is whether one or more roadside flares, partially or completed burned, could have been placed in UCD landfills at the LEHR Superfund site. Without monitoring for perchlorate, it is not possible to know if this is a problem at this site.

Another widespread new pollutant was discussed by Dr. K. Hooper (2003) of the Hazardous Materials Laboratory, Department of Toxic Substances Control, California EPA. In his abstract, he states,

"Over the past 25 years, tens of thousands of new chemicals ( 7 chemicals per day) are introduced into commerce after evaluation by USEPA. Few (100-200) of the 85,000 chemicals presently in commerce are regulated. We have reasons to believe that a much larger number than 200 adversely affect human health and the environment."

As an example of unidentified hazardous chemicals in the environment, Hooper discussed finding PBDE (polybrominated diphenyl ether) in human breast milk. Archived human breast milk shows that this is a problem that has been occurring for over 20 years. According to McDonald (2003) of California 
Environmental Protection Agency, Office of Environmental Health Hazard Assessment,

"Approximately 75 million pounds of PBDEs are used each year in the U.S. as flame retardant additives for plastics in computers, televisions, appliances, building materials and vehicle parts; and foams for furniture. PBDEs migrate out of these products and into the environment, where they bioaccumulate. PBDEs are now ubiquitous in the environment and have been measured in indoor and outdoor air, house dust, food, streams and lakes, terrestrial and aquatic biota, and human tissues. Concentrations of PBDE measured in fish, marine mammals and people from the San Francisco Bay region are among the highest in the world, and these levels appear to be increasing with each passing year."

PBDEs are similar to PCBs and are considered carcinogens. Some of the PBDEs are being banned in the US and in other countries.

A credible Superfund/hazardous chemical site investigation should include recognition that chemicals like perchlorate, PBDEs, etc., are present in mixtures of wastes. This is especially true where there is evidence that there is elevated TOC or TDS in waters derived from or associated with wastes. Further, when new widespread pollutants are found at other locations that could be present in LEHR site wastes, the water, soils and wastes should be analyzed for them. The situation at LEHR is applicable to many other Superfund/hazardous chemical sites where a mixture of chemicals are present in wastes, soils, groundwaters and surface water runoff.

One of the key issues that needs to be considered in any hazardous chemical site investigation is whether there is the possibility of a technically valid "clean closure" of the site. As discussed by Lee and Jones-Lee (1994), it should not be assumed that meeting water quality standards/MCLs (drinking water maximum contaminant levels) by all measured constituents means that waters derived from or influenced by the site are "safe" and/or will not be adverse to public health and the environment. Hazardous chemical sites can readily contain hazardous or deleterious chemicals that will in the future be found to cause adverse impacts on public health and the environment. There are a number of examples of this type of situation, one of the most notorious of which is perchlorate pollution of groundwaters and surface waters. A few years ago, the widespread perchlorate pollution of surface and groundwaters, which first occurred many years ago, was unknown, primarily because perchlorate was not measured as one of the parameters in site investigation and remediation. 
In addition to the discovery of new hazardous chemicals, there is also the issue of changing the standards of "safe" concentrations of well-known hazardous chemicals. A situation of this type occurred with chromium-VI, where in California there is concern that the $50 \mu \mathrm{g} / \mathrm{L}$ drinking water MCL is not adequate to protect public health. A similar situation exists with respect to arsenic, where, for political reasons, arsenic is not regulated using the same approach as the rodent carcinogens. While arsenic is a known carcinogen that has been repeatedly found to cause cancer in humans, many of the rodent carcinogens (such as some of the chlorinated solvents) have never been found to cause cancer in humans at concentrations of solvents commonly found in groundwaters.

Significance of "Non-hazardous" Chemicals. The US EPA Superfund program focuses on the control of a few hazardous chemicals at a limited number of hazardous chemical sites. There are, however, a wide variety of so-called "nonhazardous" chemicals at Superfund/hazardous chemical sites that can be significantly detrimental to the use of the site and nearby areas. Some of the effects of concern on groundwaters include tastes and odors, total dissolved solids, hardness, iron and manganese staining, and unknown/known chemicals that can adversely affect public health or the environment. The US EPA does not necessarily require the control of these chemical effects to eliminate adverse impacts to public health and the environment. They may, however, be covered in Applicable or Relevant and Appropriate Requirements (ARARs).

There are situations where a US EPA region has allowed Superfund site remediation for a chlorinated solvent such as TCE through air-stripping, but not required that the other host of non-regulated chemicals, which can cause tastes and odors or be adverse to public health and the environment, be cleaned up from the site, since they are not on the Priority Pollutant list. From the public's perspective, removal of the TCE from the water, but leaving it so that it is not drinkable because of tastes and odors or other aesthetic problems, is strongly contrary to common sense, effective protection of resources and, for that matter, public health and environmental protection. If there are taste- and odor-producing compounds in the water arising from unknown organics, there could also be hazardous chemicals present in the water/soils that have not been measured by the chemical tests used.

Another deficiency in the LEHR site investigation is that the Central Valley Regional Water Quality Control Board has a Basin Plan requirement of protecting groundwaters from pollution by tastes and odors. This should be an ARAR for the LEHR site remediation. DSCSOC has pointed out that in order to 
evaluate the pollution of groundwaters by UCD landfilled wastes, the groundwaters that have been polluted by these wastes should be evaluated for the presence of tastes and odors using taste and odor testing. This is especially relevant since the groundwaters that have been polluted by LEHR site wastes have elevated total organic carbon (TOC). This TOC could readily contain unidentified inorganic and organic hazardous and deleterious chemicals that impair its use for domestic and some other purposes.

\section{Stormwater Runoff Monitoring and Impact Assessment}

One of the most significant deficiencies with current Superfund/hazardous chemical site investigations at many sites is an inadequate stormwater runoff monitoring program to assess the impacts of hazardous/deleterious chemicals derived from the site on the beneficial uses of the receiving waters for the site's stormwater runoff. This problem is of sufficient magnitude so that the authors have developed several reviews of it. As discussed by Lee and Jones-Lee (1998, 1999), one of the most frequent problems with Superfund/hazardous chemical sites' stormwater runoff impact evaluation is the use of a technically invalid approach of assuming that if a regulated chemical is present at less than detection limits, it is not adverse to public health and/or the environment. Analytical methods used in stormwater runoff and ambient water monitoring should have reliable detection limits (quantitation limits) of at most (and preferably less than) 0.5 times the US EPA water quality criterion/MCL for the constituent being measured. In order to assess whether a detection limit for a constituent is adequate to prevent adverse impacts to public health and the environment, it is important to know and understand the current water quality criteria/standards that exist for the potential impacts of the chemical constituent.

The US EPA (2002a) has recently updated its National Recommended Water Quality Criteria. This publication provides the latest available information on potential toxicity and excessive bioaccumulation of regulated chemicals in aquatic systems. If the analytical methods that are chosen for the site investigation do not have adequate detection limits to reliably measure the constituent of concern at and below the water quality criterion, then more sensitive methods need to be utilized.

Some of the more common problems in stormwater runoff water quality monitoring at hazardous chemical sites include an unreliable assessment of "no impact," where those conducting the assessment use drinking water MCLs to assess the potential effects on aquatic life. This situation arises from those who are responsible for Superfund site investigation typically having a geology/ engineering background, with little or no formal training in water quality. They 
fail to understand that concentrations of chemicals that are adverse to aquatic life through direct toxicity, or to humans through bioaccumulation in aquatic life, can occur at many orders of magnitude lower concentrations than those that are adverse to humans who consume the water for domestic purposes.

Another common problem is the failure to use aquatic life toxicity as an assessment tool for evaluating the impact of stormwater runoff from hazardous chemical sites. The chemical-specific approach addresses only a small number of the potentially toxic constituents present in hazardous chemical site stormwater runoff. Aquatic life toxicity tests should be done, using the US EPA standard three-species tests (US EPA 2002b,c,d), involving Ceriodaphnia dubia (freshwater zooplankton), Pimephales promelas (fathead minnow larvae) and Selenastrum capricornutum (an alga). If toxicity is found in the runoff, then there is need to evaluate the potential significance of the runoff-associated toxicity on impacting the beneficial uses of the receiving waters for the runoff. This will typically involve measurement of the fate, persistence, magnitude and duration of toxicity and the impacts on the numbers and types of organisms present in the receiving water's water column and sediments that are potentially affected by it. Lee and Jones-Lee (2002a) have discussed the approach that should be used in making this evaluation.

PRGs (preliminary remediation goals) are widely used at Superfund sites to assess the potential for contaminated soils to be a threat to public health. This approach, however, is not reliable for predicting the potential public health impacts of constituents in soils subject to stormwater runoff, since PRGs do not consider the bioaccumulation of hazardous chemicals such as the organochlorine pesticides, PCBs, mercury, etc., in receiving water aquatic life.

In addition to evaluating the potential toxicity in the stormwater runoff from the hazardous chemical site, there is also need to evaluate whether constituents in the stormwater runoff or in the receiving waters when mixed with stormwater runoff from the site, are converted to toxic forms downstream of the site. Toxicity monitoring should, therefore, include not only the point of discharge, but also at several locations downstream from the point of discharge during times of discharge.

Failure to detect aquatic life toxicity in standard US EPA toxicity tests does not mean that the chemicals present are not toxic to aquatic life. A comparison between US EPA water quality criteria for potentially toxic chemicals and the concentrations of these chemicals that can be adverse to aquatic life 
through toxicity shows that often the sensitivity of the toxicity test is not adequate to detect low levels of extended toxicity.

Another area that is almost universally ignored is that of hazardous chemicals in stormwater runoff from the site that bioaccumulate in receiving water aquatic life that are used as food, to a sufficient extent to be hazardous to those who eat the fish and shellfish. Such errors as consulting firms working for PRPs claiming that, if the waters are nontoxic to aquatic life, there will be no problem with bioaccumulation, have occurred at the LEHR site. These errors arise from the fact that, often, the consulting firms do not have individuals on their staff with a sufficient understanding, and the remediation program managers for a site do not have a sufficient understanding, of water quality issues to properly assess surface water impacts of stormwater runoff-associated constituents.

With increasing attention being given to the impacts of hazardous chemical discharges/runoff on receiving water beneficial uses through causing toxicity to sediment-associated benthic and epibenthic organisms or serving as a reservoir for excessive bioaccumulation in aquatic life present in the receiving water sediments, there is need to incorporate receiving water sediment toxicity testing and measurement of the potential for bioaccumulation in aquatic life of hazardous chemicals present in the sediments, which could lead to excessive bioaccumulation in higher trophic level organisms.

The US EPA (2000) has discussed the need for sediment bioaccumulation testing procedures to evaluate whether chemicals like the "legacy" pesticides and PCBs, which tend to strongly sorb to particulates (sediments), are bioavailable to lead to excessive bioaccumulation in higher trophic level (edible) fish. The US EPA (1994) has developed a standard benthic organism bioavailability test involving the use of Lumbriculus variegatus (oligochaete-worm). As discussed by Lee and Jones-Lee (2002a,b), the first step in evaluating whether a particular discharge/runoff is the source of hazardous chemicals that are bioaccumulating to hazardous levels in edible fish in the receiving waters for the runoff/discharge is to determine whether the edible fish or other aquatic life in the receiving waters have excessive concentrations of one or more hazardous chemicals in their edible tissue. If the fish in the receiving water have excessive concentrations of a hazardous chemical that is a threat to human health or higher trophic level organisms, then the US EPA (1994) procedure should be used to evaluate whether sediments that receive stormwater runoff from a hazardous chemical site are a potential source of the pesticides, PCBs, mercury or other hazardous chemicals that are bioaccumulating to excessive levels in fish. 
Chlordane, formerly used for flea control on dogs, has been a stormwater runoff monitoring parameter at the LEHR Superfund site. While essentially all the measurements made show chlordane concentrations below the analytical method detection limits used, there was one measurement with chlordane in the stormwater runoff above the detection limit. A comparison between the US EPA water quality criterion for chlordane that could lead to excessive bioaccumulation in aquatic life and the detection limits used to monitor chlordane in stormwater runoff shows that chlordane could be present in stormwater runoff from the LEHR site that could bioaccumulate to excessive levels in receiving water fish, even though it was not detected in the runoff or receiving waters.

In addition to concern about excessive bioaccumulation being a health hazard to people and to higher trophic level organisms that use aquatic organisms as food, there is also concern about the toxicity of bioaccumulated residues in the host organism, such as fish, to this organism. As part of developing regulatory approaches for disposal of contaminated dredged sediments, the US Army Corps of Engineers (US ACOE, 1997) developed "The Environmental Residue-Effects Database (ERED)." This database is a compilation of information on the concentrations of chemicals in aquatic organism tissue and their apparent effects on aquatic life. The ERED is available electronically. It was last updated June 2001. It contains 3,463 results of 736 studies on 188 species for 222 analytes.

The issue of critical concentrations of bioaccumulatable chemicals in aquatic life tissue is one that has also been addressed by the US EPA. Jarvinen and Ankley (1999) have published a review, Linkage of Effects to Tissue Residues: Development of a Comprehensive Database for Aquatic Organisms Exposed to Inorganic and Organic Chemicals. This publication presents a comprehensive, critically-reviewed, literature-based assessment of the concentrations of chemicals found in aquatic organisms relative to observed effects on the organisms. The Jarvinen and Ankley (1999) database has over 3,000 entries for 200 chemicals, and is based on 500 references. As an example, the organochlorine "legacy" pesticide database includes 15 organochlorine pesticides, with 473 endpoints and 91 references, representing 68 aquatic species, 46 of which were freshwater. The host organism toxicity databases should be used to evaluate whether measured tissue residues are potentially hazardous to the host organism.

Mercury. The situation that occurred at the UCD/DOE LEHR national Superfund site, with respect to evaluating the presence of mercury, is an example of inappropriate approaches that occur in investigating stormwater runoff-associated 
impacts from Superfund sites. In the mid-1990s when the authors became US EPA-sponsored TAG advisors for the LEHR Superfund site, it was found that the evaluation that was being done of stormwater runoff from the site was inadequate and in error in several respects. There are a couple of constituents potentially present at the LEHR site that could be present in stormwater runoff that needed to be evaluated, with respect to bioaccumulating to excessive levels in receiving water fish. The receiving water for the LEHR site stormwater runoff is Putah Creek, a small waterbody that, at times, has very low flow.

In an effort to see if the LEHR site stormwater runoff could be contributing to excessive bioaccumulation in Putah Creek fish, the authors were able to get the Agency for Toxic Substances and Disease Registry (ATSDR) to work with the US EPA Region 9 to conduct a survey of heavy metal and organochlorine pesticide/PCB concentrations in Putah Creek fish near the LEHR site. ATSDR (1997) found that the fish in Putah Creek near the LEHR site, which is also an area where UCD discharges its campus wastewaters, had excessive concentrations of mercury, compared to those that are considered a hazard if the fish are to be used as food. It was unclear at that time as to whether the excessive bioaccumulation of mercury was due to mercury derived from upstream sources, the campus wastewater treatment plant discharges and/or stormwater runoff from the LEHR site.

A follow-on study was conducted by ATSDR (1998) at higher flows, which showed that some fish throughout the area of study contained excessive concentrations of mercury. This led to UCD sponsoring its own study, which confirmed that fish throughout Putah Creek had excessive concentrations of mercury. This mercury was derived from former mercury mining activities in the headwaters of Putah Creek, as well as possibly from campus wastewater discharges and stormwater runoff from the LEHR site.

Throughout this period, the analytical methods used to measure mercury in stormwater runoff from the LEHR site were significantly deficient compared to the detection limits needed to determine, under worst-case conditions, whether stormwater runoff from the LEHR site contained mercury at sufficient concentrations to bioaccumulate to excessive levels. The US EPA (1987) defined this level as $20 \mathrm{ng} / \mathrm{L}$ total recoverable mercury. Subsequently, as reported by Lee (2003a), the US EPA has found that the worst case bioaccumulation of mercury requires that the total recoverable mercury be less than about $5 \mathrm{ng} / \mathrm{L}$. Lee discussed that the US EPA (2001) has proposed to change the approach for regulating mercury to edible fish tissue residue of $0.3 \mathrm{mg} / \mathrm{kg}$ and a site-specific bioaccumulation factor for a particular waterbody. 
Subsequently, based on DSCSOC's repeated requests, the RPMs for the LEHR site required that the PRPs (UCD and DOE) use analytical procedures that had adequate detection limits for detecting the potential for excessive bioaccumulation. When this was done, it was found that the mercury concentrations in the stormwater runoff were about 5 to 20 times higher than the worst-case potential bioaccumulation values that the US EPA had established in the mid-1980s, of $20 \mathrm{ng} / \mathrm{L}$. It is, therefore, concluded that the LEHR site stormwater runoff, which contains significantly elevated mercury compared to those levels that can cause excessive bioaccumulation of mercury, could be a contributor to the mercury problem that occurs in Putah Creek fish.

Receiving water sediments potentially influenced by hazardous chemical site stormwater runoff should also be tested for aquatic life toxicity using the US EPA (1994) standard sediment test organism Hyalella azteca (amphipod). If toxicity is found, then sediment-based TIEs and/or sediment toxicity forensic studies should be used to determine the cause of the toxicity and its origin. Guidance on conducting these studies is provided by Lee and Jones-Lee (2002a,b).

\section{Translocation}

The US EPA Superfund site investigation guidance as well as some state Superfund or hazardous chemical site investigation guidance, does not require investigating the potential for terrestrial plants present at the site to translocate (take up through the roots) hazardous chemicals and discharge them to the environment through the leaves and flowers. Translocation is a well-known mechanism for remediation of hazardous chemical sites, using terrestrial vegetation to remove the pollutants from the soils. The constituents present in the soils at a Superfund site could, at some time in the future when in contact with certain types of terrestrial plant roots, be brought to the surface through the plant system and released to the environment, thereby representing a threat to animals that utilize the site, as well as to humans, through stormwater runoff and site utilization.

In the case of the LEHR site, while the RPMs for this site did not support DSCSOC's request that translocation be investigated, it was subsequently found, upon removal of a tree, that the tree trunk had high levels of tritium that had been obviously picked up from the UCD waste that had been deposited at the site. Even after this finding, the RPMs still did not require that translocation be investigated. It is still not known whether translocation is an important route for 
transfer of hazardous chemicals present in the LEHR site soils and wastes to the environment.

\section{Inadequate Investigation of Groundwater Pollution}

Many Superfund/hazardous chemical sites have considerable groundwater pollution. At the LEHR site, a chloroform-based groundwater pollution plume extends approximately a mile from the location where UCD dumped waste chloroform in the landfill. A second plume of similar magnitude exists at another landfill that UCD has developed. It is also known that, through inter-aquifer connections associated with transfer through well bore holes, there has been pollution of the primary drinking water aquifer for the Davis area by chloroform and possibly other constituents.

While the offsite groundwater pollution at the LEHR site was identified in the late 1980s, in 2003 UCD still has not identified the full extent of offsite groundwater pollution by mismanagement of campus wastes. While the UCD campus pollution of groundwaters polluted agricultural wells, UCD was extremely lucky in not polluting domestic water supplies by chloroform and other hazardous chemicals. The current UCD administration claims that the chloroform pollution of groundwaters is not that significant based on the fact that chlorinated domestic water supplies are allowed to have concentrations of chloroform well above the acceptable risk-based concentration for protection of human health. However, the drinking water MCL for chloroform is a compromise value that represents a "balancing" between adequate disinfection of the water through the use of chlorine and the health risks associated with consuming waters with chloroform, which is regulated as a carcinogen. Chloroform introduced to the environment as a waste is regulated differently than chloroform that arises from chlorination of domestic water supplies.

All Superfund sites should, as a highest priority, reliably define the full extent of the groundwater pollution plumes and how these plumes change as a function of remediation efforts. This will require comprehensive long-term monitoring of the plume. It will be important that adequate funds be committed ad infinitum for Superfund/hazardous chemical monitoring.

Natural remediation of polluted groundwaters is an approach that some PRPs and regulatory agencies adopt in order to reduce the cost of groundwater remediation. An example of inappropriate approaches that have been adopted for remediation of gasoline-polluted groundwaters from leaking underground storage tanks occurred where those advocating natural remediation of the gasolinepolluted groundwaters only defined the plume based only on benzene, toluene and 
xylene, all of whose movement through groundwater is retarded through sorption reactions and all of which slowly degrade in groundwater. The advocates of natural remediation, such as some of the staff from the Lawrence Livermore National Laboratory who were serving as advisors to the California State Water Resources Control Board, ignored that gasoline is a far more complex mixture of hazardous chemicals than just benzene, toluene and xylene. The inappropriateness of this approach was resoundingly demonstrated when it was found that MTBE, which is an additive to gasoline, moves freely through groundwaters and is very slowly degraded. Natural remediation of groundwater ignored the MTBE problem. The natural remediation approach should only be used where there is a well-defined, limited number of pollutants in the groundwater and the hydrogeology of the area is simple and has been adequately defined.

Dissolved oxygen is a parameter that should be measured in all groundwater samples. This measurement should be made with down borehole instrumentation at the time just after purging the well. DO, EC and temperature should also be measured. The DO measurements are important in determining the overall chemical regime that exists in the groundwater system. Certain chemicals, such as chromium-VI are transported to a greater degree under oxic or oxidized conditions than under reducing conditions. Chromium-VI, which is the most hazardous form of chromium, is sorbed poorly and is readily transported in groundwaters, while chromium-III (the reduced form) tends to be strongly sorbed on aquifer solid surfaces, and therefore would not be expected to be transported for considerable distances. While some investigators attempt to use redox potential measurements as a measure of oxidizing versus reducing conditions, dissolved oxygen measurements are much more reliable, as a result of the fact that there is difficulty in reliably measuring redox potential.

There is controversy at the LEHR site about the origin of the elevated concentrations of chromium-VI present in site groundwaters. Some of the groundwaters contain chromium well above the US EPA drinking water MCL. It is known that chromium is present naturally in the geological strata in the general vicinity of the LEHR site as a result of private domestic water supply wells not influenced by the LEHR site having been found to contain chromium at or above the drinking water MCL. There is concern, however, about whether UCD's deposition of wastes at the LEHR site has led to the pollution of groundwaters by waste-derived chromium. Detailed field studies will need to be conducted upgradient and downgradient of various waste management units at the LEHR site in order to determine whether UCD's deposition of wastes has contributed to the elevated chromium in the groundwaters. 
While chromium tends to be mobile under oxidizing conditions, the reverse is true for manganese. Manganese-II, which is present in oxygen-free conditions, tends to be transported in groundwaters, and manganese-IV, in the form of $\mathrm{MnO}_{2}$, is not transported, since it exists as a precipitate. The presence or absence of dissolved oxygen in groundwaters can affect the persistence of chlorinated solvents. Reducing (oxygen-free) conditions can convert a number of the chlorinated solvents, such as TCE, to vinyl chloride, which is persistent in groundwaters. Vinyl chloride is a highly hazardous known human carcinogen.

Electrical conductivity is a useful parameter for indicating different water masses in the groundwater aquifer system. If the EC changes from one well to the next, it is known that there are significantly different water masses, since changes in EC reflect bulk changes in the composition of the groundwater.

There is controversy about the appropriateness of measuring total versus dissolved metals in groundwaters. While PRPs and some regulatory agencies assert that particulate metals reflect the composition of the aquifer materials as opposed to the groundwater, that assertion may not be reliable. It is inappropriate to only measure dissolved metals, since the process of sampling the groundwater can lead to a change in the distribution between dissolved and particulate forms of the metals and other constituents. This is especially true when the samples contain turbidity arising from inadequately constructed/developed sampling wells. All groundwater sampling should include measurements of both total and dissolved forms of constituents, with the understanding that the actual concentrations of the constituent in the groundwater is likely to be at a concentration between the two measurements.

\section{Unreliable Vadose Zone Transport Modeling}

A problem that occurs at some Superfund sites is that the PRPs and their consultants attempt to predict transport of waste-associated constituents from the place of deposition to the groundwater table through the use of unsaturated transport models. The validity of such modeling depends to a considerable extent on the approach used to estimate transport of constituents as a function of the moisture content within the vadose zone. The situation that existed at the LEHR site, where the DOE contractor attempted to use average annual moisture content within the vadose zone to predict the rate of transport of pollutants in the soil, ignores the well-known fact that the transport of potential pollutants in the vadose zone is based not on average annual moisture content, but primarily on wetted front conditions associated with precipitation and/or irrigation events. Typically, most of the transport of mobile materials through the vadose zone occurs during 
the short periods of time when essentially saturated conditions exist. Using this approach, a significantly different vadose zone transport is found than based on the average annual moisture content. For example, using average annual moisture content at the LEHR site results in a prediction of nitrate transport through the vadose zone requiring about 30 years. In fact, nitrate transport through the vadose zone occurs in about one to three years.

While there are some, such as the UCD LEHR site consultants, who claim that it is possible to monitor for transport of pollutants through the soil column by measuring concentrations in soils, this is not a reliable approach, especially near the surface in arid climates where there is an accumulation of pollutants into fairly narrow bands, which are then transported as a result of evaporation of soil moisture near the surface. These bands of chemicals can then move in a wetted front to the saturated groundwaters during a precipitation event.

As part of attempting to predict the rate at which residual potential pollutants in hazardous chemical site soils and wastes will migrate through the vadose zone to groundwater, PRPs and their consultants will at times try to use pure-solution-derived partition coefficients for predicting the partitioning of a pollutant between water and the solid phase in the unsaturated, as well as saturated, part of the aquifer. Such predictions can be of limited reliability. The problem with this approach is that, in complex mixtures of wastes, the pollutant can show a significantly different partitioning from pure solution situations because of interactions between the pollutant and other constituents in the wastes. Further, other constituents which may not interact with the pollutant of concern can change the surface character of the aquifer solids, so that they no longer act as predicted under laboratory pure conditions. These various interactions can cause pure solution predictions on the constituents that tend to partition between water and solids to, in some cases, underestimate rates of transport, and in others, overestimate this rate.

It is not possible to predict with a high degree of reliability the actual vadose zone transport rate. The reliable approach for determining whether a waste management unit is contributing constituents to the vadose zone is to actually measure transport. This can be done through vacuum cup lysimeters operated in such a way as to extract the transport of constituents in the pulses of water that occur with precipitation/irrigation events. This will require operations of the vacuum cup lysimeters in such a way as to exert a vacuum just slightly greater than soil moisture tension, specifically focusing on precipitation and irrigation events. 
The ultimate proof of whether constituents in a waste management unit or contaminated soils are being transported to saturated groundwater is through groundwater monitoring at the upper part of the primary aquifer just upstream and downstream of the waste management unit/contaminated area. The upgradient groundwater characteristics should not be based on site-wide characteristics, unless the site is extremely homogeneous. Most sites have sufficient variability in groundwater composition so that upgradient concentrations of constituents must be established for each waste management unit or area of contamination in order to determine whether the waste management unit, through vadose zone transport, is contributing pollutants to the groundwater through the upper part of the groundwater table.

\section{Unreliable Groundwater Monitoring}

In an effort to save funds for the PRPs, some consultants, with RPM approval, will attempt to use the hydropunch system to determine whether groundwaters have been polluted by the site. Hydropunch, however, can be unreliable, especially in some sand and gravel aquifer systems, because of the inability to penetrate to any significant depth within the aquifer. In some instances, penetrating a few inches to a foot or two into an aquifer with hydropunch may totally miss the plume that lies a few feet or more below the water table. It is inappropriate to assume that the water at the water table downgradient from a waste management unit is representative of what has been polluted in an aquifer that is tens of feet or more thick. The surface layer just under the water table often is diluted considerably from the vadose zone transport of unpolluted groundwaters downgradient of the waste management unit. Also, some wastes contain sufficient salts so that they have a density greater than that of the groundwater, and therefore tend to sink upon entering the aquifer.

The authors have frequently encountered situations where consultants on behalf of PRPs or project proponents will claim that a particular clay layer, which under remolded laboratory conditions can have a permeability of $10^{-8}$ or $10^{-9}$ $\mathrm{cm} / \mathrm{sec}$, represents an "impermeable" layer that will protect the underlying groundwater aquifer from pollution by waste management units. It is well understood, however, that laboratory measurements of permeability are not representative of what can actually occur in the field, where few clay layers do not have zones of higher permeability associated with cracks, lenses, heterogeneous composition, etc. Radioisotope dating of the water underlying the site can be a useful tool to determine whether a so-called "impermeable" stratum that separates two aquifers will prevent pollutants in the upper aquifer from being transported to the lower aquifer. 
This is an issue at the LEHR site, where UCD and its consultants claim that two aquifers that are separated by a low-permeability layer are isolated from each other except through inter-aquifer transfer through the bore-holes of production wells. Isotope dating is an approach that can be used to determine whether the groundwaters underlying a site are "old" groundwaters - i.e., have been protected from infiltration for many years - or represent waters that are being fed by surface water infiltration through zones of higher permeability than the laboratory (or even a limited number of bore-hole) permeability measurements. If the lower aquifer waters are found to be of about the same age and composition as the upper aquifer, then it is likely that there is transfer of pollutants from the upper aquifer to the lower aquifer.

\section{Unreliable Commitment to Long-Term Groundwater Monitoring}

In many situations, the residual wastes at a site that has been "remediated" represent a significant threat that can extend for many decades, or, in some situations and types of wastes, thousands of years. There are significant problems being encountered with respect to assured funding for monitoring of these sites for as long as the wastes represent a threat. The approach that should be used in a situation where there are residual wastes/hazardous components left at the site upon closure is to require that the PRP, whether public or private, develop a dedicated trust fund of sufficient magnitude to reliably monitor groundwater for as long as the wastes in the unit are a threat to cause groundwater pollution. Because of the uncertainty of this period of time, for planning purposes, the time needed for funding should be considered to be infinite. The magnitude of the dedicated trust should be sufficient to consider the reliability of the groundwater monitoring system in detecting releases, and provide funds for plausible worstcase scenario failure to detect polluted groundwaters before widespread pollution has occurred.

\section{Unreliable Data Reporting}

There are problems with approaches that are allowed to be followed by the PRPs and their consultants, where data reports are generated that contain obvious errors in how the data are reported with respect to concentration units, obvious concentration errors which are well outside of the expected range, failure to designate the form of the constituent measured (such as $\mathrm{PO}_{4}$ versus $\mathrm{P}$, or nitrate as $\mathrm{NO}_{3}$ versus $\mathrm{N}$ ) and inconsistencies between parameters that should provide similar results, such as specific conductance and total dissolved solids. At the LEHR site, year after year the RPMs allowed the PRPs and their consultants to submit data reports into the archives which contained these types of errors even after the errors were pointed out. This type of sloppy reporting will cause significant problems in the future when attempts are made to review the data that 
were generated at those sites where the RPMs allow this type of inadequate data reporting to go on.

\section{PRP Approach to Public Health and Environmental Protection}

It is the experience of the authors that the PRPs for Superfund sites, whether public or private, typically approach site investigation/remediation with the attitude of doing the least possible to get by what the remediation program managers will allow. This approach occurs even when universities - such as the University of California, Davis - are the PRPs. The University of California, Davis, has four campus landfills that are polluting groundwaters, three of which are part of a national Superfund site and the fourth is under remediation required by the Central Valley Regional Water Quality Control Board for groundwater pollution. Even with this history, the UCD administration is in the process of developing a fifth campus landfill, where even its own staff admit that it is only a matter of time until it will also pollute groundwaters. Rather than managing its campus wastes with other municipal wastes, the UCD administration persists with waste management policies that will not protect public health and the environment for as long as the wastes represent a threat.

On the one hand, the university president/chancellor will claim that the university is a leader in environmental education activities, etc., and then, at the same time, establish a policy so that the university staff are to oppose any efforts to provide for full public health and environmental protection associated with campus waste management. The RPMs in such situations find themselves in a confrontational atmosphere, where some give in to the PRPs' wishes. This is a situation where the public representative, such as under the US EPA Technical Assistance Grant program, must act to try to ensure, to the maximum extent possible, that the public's interests are protected. Further - and this is often difficult to achieve - where the situation involves some unknown hazard, the TAG advisor should work toward trying to see that the site investigation/remediation proceeds to err on the side of the public's interests, as opposed to on the side of cheaper Superfund site investigation and remediation than is needed to protect public health and the environment.

\section{Site Remediation through Onsite Landfilling}

One of the approaches that is being used to reduce the cost of Superfund site remediation is the development of onsite landfills, where all or some of the wastes/hazardous chemicals deposited at the site are managed in a RCRA landfill. Depending on the nature of the wastes, the RCRA landfill can be either Subtitle C (hazardous waste) or Subtitle D (municipal or industrial "non-hazardous” waste). For those sites where there is already a landfill on the site, the remediation can 
take the approach of a RCRA cap, or in some instances, PRPs will propose (and RPMs will allow) a "less-than-RCRA" cap on an existing landfill. Lee and JonesLee (2000, 2003b) and Lee and Jones-Lee (2003) have presented discussions of the common problems associated with onsite landfilling of non-hazardous wastes at Superfund/hazardous chemical sites as part of site remediation.

\section{Overall}

As discussed herein, there are significant problems with the approach that is being used in investigation and remediation of some - possibly many - US EPA National Priority List Superfund sites, compared to the approach that should be followed to ensure high degrees of public health and environmental protection from residual wastes/chemicals present at the remediated site. This situation is likely to get worse as even greater pressures are brought on federal and state agency staff to more rapidly remediate Superfund/hazardous chemical sites. Another factor that will play heavily in this issue is the tendency of federal and state legislatures to reduce the funding available for Superfund/hazardous chemical site investigation and remediation. This is especially true for the "orphan" sites, for which there is no identifiable PRP that has funding to conduct the investigation and remediation.

The US EPA Technical Assistance Grant advisors have an important role to play in working toward improved public health and environmental protection, with particular emphasis on working to achieve the highest quality science and engineering in site investigation and remediation. Many TAG advisors have unique experience and perspectives on Superfund site investigation and remediation. Rather than just meeting regulatory agency staff's interpretation of minimum regulatory requirements, TAG advisors can strive for more comprehensive protection of public health and the environment than provided by the US EPA, state and local regulatory agencies.

The US EPA headquarters national TAG program could enhance the ability of TAG advisors to improve the quality of Superfund site investigation and remediation, through establishing a national website where specific problem areas such as those discussed herein could be presented and discussed. This website could then serve as a technical resource to other TAG recipients and their advisors, as well as the general public.

The US EPA national TAG program should support effective communication among TAGs and their advisors, establish a registry of TAG groups and an email network with website addresses, support periodic meetings and workshops at the national and regional levels, provide for publication of 
papers and reports that discuss the experience of TAGs in site investigation and remediation, and develop a directory of resource information for TAG groups.

\section{References}

ASCE, “Sanitary Landfill," Report Committee on Sanitary Landfill Practice of the Sanitary Engineering Division of the American Society of Civil Engineers, New York, NY (1959).

ATSDR, "Health Consultation, Fish Sampling in Putah Creek; Laboratory for Energy-Related Health Research, Davis, California,” CERCLIS No. CA2890190000, US Department of Health and Human Services, Atlanta, GA, April 4 (1997).

ATSDR, "Health Consultation, Fish Sampling in Putah Creek (Phase II); Laboratory for Energy-Related Health Research, Davis, Yolo County, California," Public Comment Release, CERCLIS No. CA2890190000, US Department of Health and Human Services, Atlanta, GA, September 16 (1998).

DHS, “Perchlorate in Drinking Water: Action Level," California Department of Health Services (2003).

http://www.dhs.ca.gov/ps/ddwem/chemicals/perchl/actionlevel.htm

Friedman, D. (ed.), Waste Testing and Quality Assurance: Second Volume, STP 1062, American Society for Testing and Materials, Philadelphia, PA (1990).

GAO, "Superfund: Improved Reviews and Guidance Could Reduce Inconsistencies in Risk Assessments,” GAO/RCED-94-220, US General Accounting Office, Washington, D.C. (1994).

Hooper, K., "Lessons from the PBDEs - The Value of Monitoring Community Body Burdens Using Breast Milk," In: $6^{\text {th }}$ Bienniel State of the Estuary Conference, "The San Francisco Bay-Delta Estuary: Changes and Challenges," San Francisco Estuary Project, Oakland, CA (2003).

Jarvinen, A. W. and Ankley, G. T. Linkage of Effects to Tissue Residues: Development of a Comprehensive Database for Aquatic Organisms Exposed to Inorganic and Organic Chemicals. Society for Environmental Toxicology and Chemistry. SETAC Press: Pensacola, FL. (1999). 
Lee, G. F., "Redevelopment of Brownfield Properties: Future Property Owners/Users Proceed with Your Eyes Open," Environmental Progress 16(4):W3-W4 (1997). http://www.gfredlee.com/brownfield.html

Lee, G. F., "Regulating Mercury in the Water Column and Sediments," Report to Dredge Tailings Workgroup, by G. Fred Lee \& Associates, El Macero, CA (2003a).

http://www.gfredlee.com/TotalMercuryandDissolvedMercuryStandards-rev.pdf

Lee, G. F., "Improving the Quality of Science/Engineering in Superfund Site Investigation \& Remediation II: Onsite Landfilling," Presentation at the US EPA Technical Assistance Grant Workshop, Albuquerque, NM, February (2003b). http://www.gfredlee.com/Show-SuperfundAlbuquerque.pdf

Lee, G. F. and Jones, R. A., "Redevelopment of Remediated Superfund Sites: Problems with Current Approaches in Providing Long-Term Public Health Protection,” Proc. Environmental Engineering 1991 Specialty Conference, ASCE, New York, pp. 505-510, July (1991a). http://www.gfredlee.com/remsprfd.htm

Lee, G. F. and Jones, R. A., "Evaluation of Adequacy of Site Remediation for Redevelopment: Site Assessment at Remediated-Redeveloped 'Superfund' Sites," Proc. 1991 Environmental Site Assessments Case Studies and Strategies: The Conference, NWWA's Association of Ground Water Scientists and Engineers, Dublin, OH, pp. 823-837 (1991b). http://www.gfredlee.com/phazchem2.htm

Lee, G. F. and Jones-Lee, A., "Does Meeting Cleanup Standards Mean Protection of Public Health and the Environment?" In: Superfund XV Conference Proceedings, Hazardous Materials Control Resources Institute, Rockville, MD, pp. 531-540 (1994). http://www.gfredlee.com/hmcrstd.htm

Lee, G. F. and Jones-Lee, A., "Hazardous Chemical Site Remediation Through Capping: Problems with Long-Term Protection,” Remediation 7(4):51-57 (1997). http://www.gfredlee.com/pbrwnfld.htm

Lee, G. F. and Jones-Lee, A., "Stormwater Runoff Water Quality Evaluation and Management Program for Hazardous Chemical Sites: Development Issues," Superfund Risk Assessment in Soil Contamination Studies: Third Volume, ASTM STP 1338, American Society for Testing and Materials, pp. $84-98$ (1998). http://www.gfredlee.com/stmhzpap.htm 
Lee, G. F. and Jones-Lee, A., "Evaluation of Surface Water Quality Impacts of Hazardous Chemical Sites,” Remediation 9:87-118 (1999).

http://www.gfredlee.com/eval_sfcwaters.pdf

Lee, G. F. and Jones-Lee, A., "Evaluation of the Adequacy of Hazardous Chemical Site Remediation by Landfilling," In: Remediation Engineering of Contaminated Soils, Marcel Dekker, Inc., New York, NY, pp. 193-215 (2000a).

http://www.gfredlee.com/chem_remed.pdf

Lee, G.F. and Jones-Lee, A., "Improved Public Health and Environmental Protection Resulting from Superfund Site Investigation/Remediation: UCD/DOE LEHR Superfund Site Davis, California,” Technical Advisors to Davis South Campus Superfund Oversight Committee, DSCSOC, Presented at US EPA National TAG Conference Nashville, Tennessee, September 15-16, (2000b). http://members.aol.com/dscsoc4/2000/tag_082900.pdf

Lee, G. F. and Jones-Lee, A., "Issues in Developing a Water Quality Monitoring Program for Evaluation of the Water Quality - Beneficial Use Impacts of Stormwater Runoff and Irrigation Water Discharges from Irrigated Agriculture in the Central Valley, CA,” California Water Institute Report TP 02-07 to the California Water Resources Control Board/ Central Valley Regional Water Quality Control Board, 157 pp, California State University Fresno, Fresno, CA, December (2002a). http://www.gfredlee.com/Agwaivermonitoring-dec.pdf

Lee, G. F. and Jones-Lee, A., “Organochlorine Pesticide, PCB and Dioxin/Furan Excessive Bioaccumulation Management Guidance,” California Water Institute Report TP 02-06 to the California Water Resources Control Board/Central Valley Regional Water Quality Control Board, 170 pp, California State University Fresno, Fresno, CA, December (2002b). http://www.gfredlee.com/OClTMDLRpt12-11-02.pdf

Lee, G. F. and Jones-Lee, A., "'Superfund' Site Remediation by Landfilling Overview of Landfill Design, Operation, Closure and Postclosure Care Relative to Providing Public Health and Environmental Protection for as Long as the Wastes in the Landfill will be a Threat," Presentation at the US EPA Technical Assistance Grant Workshop, Albuquerque, NM, February (2003). Submitted for publication. PowerPoint slides available at http://www.gfredlee.com/Show-SuperfundAlbuquerque.pdf

McDonald, T. A., "The Risk Posed by the PBDEs, A Class of Flame Retardants," In: $6^{\text {th }}$ Bienniel State of the Estuary Conference, "The San Francisco Bay-Delta 
Estuary: Changes and Challenges,” San Francisco Estuary Project, Oakland, CA (2003).

Silva, M. A., “Safety Flares Threaten Water Quality with Perchlorate,” Report of Santa Clara Valley Water District, July (2003).

http://www.valleywater.org/Water/Water_Quality/Protecting_your_water/_Lustop /Perchlorate.shtm

US ACOE, “The Environmental Residue-Effects Database (ERED).” Home Page $<$ http://www.wes.army.mil/el/ered/index.html> U.S. Army Corps of Engineers, webdate: November 4. (1997).

US EPA, Quality Criteria for Water 1986, US Environmental Protection Agency, Office of Water Regulations and Standards, EPA 440/5-86-001, Washington, D.C., May (1987).

US EPA, "Guidance for Conducting Remedial Investigations and Feasibility Studies under CERCLA,” US Environmental Protection Agency, Washington, D.C. (1988a)

US EPA, "Biological Test Methods," Proc. Symposium on "Waste Testing \& Quality Assurance, Volumes I and II,” US Environmental Protection Agency, Washington, D. C., July (1988b).

US EPA, "Methods for Measuring the Toxicity and Bioaccumulation of Sediment-Associated Contaminants with Freshwater Invertebrates," US Environmental Protection Agency, EPA/600/R-94/024, Washington, D.C., June (1994).

US EPA, "Bioaccumulation Testing and Interpretation for the Purpose of Sediment Quality Assessment: Status and Needs,” EPA-823-R-00-001, US Environmental Protection Agency, Washington, D.C., February (2000).

US EPA, "Water Quality Criteria for the Protection of Human Health: Methylmercury," EPA-833-F-01-001, US Environmental Protection Agency, Office of Water, Washington, D.C. (2001).

US EPA, “National Recommended Water Quality Criteria: 2002,” EPA-822-R02-047, US Environmental Protection Agency, Washington, D.C., November (2002a). 
US EPA, "Short-Term Methods for Estimating the Chronic Toxicity of Effluents and Receiving Water to Marine and Estuarine Organisms," US Environmental Protection Agency, Washington, D.C. (2002b).

http://www.epa.gov/OST/WET/disk1/

US EPA, "Methods for Measuring the Acute Toxicity of Effluents and Receiving Waters to Freshwater and Marine Organisms," Fifth Edition, US Environmental Protection Agency, Office of Water, Washington, D.C. (2002c). http://www.epa.gov/OST/WET/disk2/

US EPA, "Short-Term Methods for Estimating the Chronic Toxicity of Effluents and Receiving Water to Freshwater Organisms," EPA-821-R-02-013, US Environmental Protection Agency, Office of Water, Washington, D.C. (2002d). http://www.epa.gov/OST/WET/disk3/

\section{About the Authors}

Dr. G. Fred Lee is President of G. Fred Lee \& Associates, a specialty environmental consulting firm focusing on water quality and solid and hazardous waste investigation and management. He has a Master of Science in Public Health degree, and a $\mathrm{PhD}$ degree from Harvard University in environmental engineering. For 30 years he taught and conducted research at several major US universities.

Dr. Anne Jones-Lee is Vice President of G. Fred Lee \& Associates. She has a bachelors degree in biology, and masters and $\mathrm{PhD}$ degrees in environmental sciences. For 11 years she held university graduate-level professorial teaching and research positions in environmental engineering and environmental sciences.

Further information on the authors' expertise, experience and activities is available from their website, www.gfredlee.com. 